Editorial

\title{
Interdisciplinary Approaches to Emotions in Politics and International Relations
}

\author{
Alex Prior ${ }^{1, *}$ and Yuri van Hoef ${ }^{2}$ \\ ${ }^{1}$ School of Politics and International Studies, Faculty of Education, Social Sciences and Law, University of Leeds, Leeds, \\ LS2 9JT, UK; E-Mail: a.m.prior@leeds.ac.uk \\ 2 History of International Relations, Department of History and Art History, Faculty of Humanities, Utrecht University, \\ 3512 BS Utrecht, The Netherlands; E-Mail: y.vanhoef@uu.nl \\ * Corresponding author
}

Submitted: 12 November 2017 | Published: 28 December 2018

\begin{abstract}
The 'emotional turn' within the social sciences and humanities attracts increasing scholarly attention. Political Science, traditionally emphasising the 'rational' public sphere rather than the 'emotional' private sphere, has increasingly questioned this dichotomisation, identifying broader political concepts and practices. The international political process-frequently characterised by widespread distrust, populist campaigns and extreme rhetoric-necessitates addressing and examining its underlying emotions. Informal, affective manifestations of politics are enormously influential, profoundly shaping inter- and intra-national democracy; they accordingly require interdisciplinary study. This thematic issue of Politics and Governance includes disciplines as diverse as education, history, international relations, political theory, psychology, and sociology. In doing so, we illustrate that emotions are cross-disciplinary concerns, relevant beyond the study of politics.
\end{abstract}

\section{Keywords}

affect; emotions; friendship; individualisation; interdisciplinary; international relations; narratives; political history; political science

\section{Issue}

This editorial is part of the issue "Interdisciplinary Approaches to Studying Emotions within Politics and International Relations", edited by Alex Prior (University of Leeds, UK) and Yuri van Hoef (Utrecht University, The Netherlands).

(C) 2018 by the authors; licensee Cogitatio (Lisbon, Portugal). This article is licensed under a Creative Commons Attribution 4.0 International License (CC BY).

\section{Introduction}

The emotional turn in the humanities and social sciences, especially within the discipline of international relations (IR), attracts considerable scholarly acknowledgement. This thematic issue of Politics and Governance presents multiple methodologies which have proven successful in elucidating this concept. In that vein, it cites recent works such as Researching Emotions in International Relations: Methodological Perspectives on the Emotional Turn (Clément \& Sangar, 2018), and studies of the role that individual actors play in IR (Jacobi \& Freyberg-Inan, 2015), as well as Nussbaum's (2013, 2001) writings on the formation of diplomatic ties through encouraging certain emotions (sympathy, for example) and openly contesting others (such as disgust).

The relevance of this academic approach is clear within the current geopolitical landscape, increasingly characterised by brinkmanship and populist rhetoric. Investigating 'celebrity politics', politicians as 'personas', and the modes of communication underlying these topics, is crucial. The relevance of emotions to individualisation applies to studies of political leaders and elites (Berenskoetter \& Van Hoef, 2017; Van Hoef, 2018) and of citizenries, increasingly characterised as selfactualising, informal and affective (Beck, Giddens, \& Lash, 1994; Bennett, 2008; Loader, Vromen, \& Xenos, 2014; Manning, 2015). This development, particularly ev- 
ident among younger generations, informs academic understandings of voting and party membership (both subject to considerable volatility), as well as informal modes including petitions and activism.

Academic acknowledgement of informal political participation was encouraged by proliferating protest movements and youth activism in the late 1960s. Recent decades have seen an expanded scholarly focus on postmaterialist values, 'issue politics', and civic engagement. In the discipline of politics, the traditional dichotomisation of emotions and rationality (based fundamentally upon Cartesian mind-body dualism, and largely unquestioned since the Scottish Enlightenment) is increasingly subject to problematisation. This expanded academic scope encompasses expanding political practices and digital technologies, the latter necessitating research on online participation and dialogue. It represents a truly interdisciplinary set of concerns and investigations.

Acknowledging the contribution of psychoanalysis (in demonstrating emotions as part of rationalisation), Jenkins (2018) argues that politics, devoid of emotions, would jeopardise its own capacity to inspire. Hall (2007) conceptualises emotions as central to reasoning, collapsing the dichotomy between them. We have also observed increasing critique within sub-disciplines such as deliberative democracy, questioning Habermas' prioritisation of rationality as a means (and quantifier) of effective communication. Myriad perspectives on these topics necessitate and contextualise this thematic issue of Politics and Governance, encompassing a range of disciplines including Education, Psychology, Political Theory and Sociology. The articles are presented in a tripartite structure, as Table 1 illustrates.

\section{Interdisciplinary Approaches to Emotions in Politics and International Relations}

\subsection{Part I: Emotions in Politics}

In the opening article, Anne-Kathrin Weber (2018) reinforces the relevance of Nussbaum to studying passionate emotions, specifically their potential in encouraging social justice and societal 'love'. Weber problematises Nussbaum's theory of compassionate emotions (on the basis of 'hierarchisation' and tension with political and social reality) and, in doing so, employs Arendt's theorisation of pity. This is applied to the 2016 US election-specifically Clinton's "Love and Kindness" ads-to illustrate how these challenges threaten to come into play when compassionate emotions are utilised as political devices.

Table 1. Tripartite structure of this thematic issue.

\begin{tabular}{|c|c|c|}
\hline Part & Author(s) & Article \\
\hline \multirow[t]{4}{*}{ I. Emotions in Politics } & Anne-Kathrin Weber & $\begin{array}{l}\text { The Pitfalls of 'Love and Kindness': On the Challenges } \\
\text { to Compassion/Pity as a Political Emotion }\end{array}$ \\
\hline & Amy Skonieczny & $\begin{array}{l}\text { Emotions and Political Narratives: Populism, Trump } \\
\text { and Trade }\end{array}$ \\
\hline & Jo Warner & $\begin{array}{l}\text { Emotional Interest Representation and the Politics of } \\
\text { Risk in Child Protection }\end{array}$ \\
\hline & Alex Prior & $\begin{array}{l}\text { Getting the Story Right: A Constructivist Interpretation } \\
\text { of Storytelling in the Context of UK parliamentary } \\
\text { engagement }\end{array}$ \\
\hline \multirow[t]{3}{*}{ II. Conceptual Approaches } & Anna Durnova & $\begin{array}{l}\text { Understanding Emotions in Policy Studies through } \\
\text { Foucault and Deleuze }\end{array}$ \\
\hline & Rosa Sanchez Salgado & $\begin{array}{l}\text { The Advocacy of Feelings: Emotions in EU-Based Civil } \\
\text { Society Organizations' Strategies }\end{array}$ \\
\hline & $\begin{array}{l}\text { Yuri van Hoef } \\
\& \text { Andrea Oelsner }\end{array}$ & $\begin{array}{l}\text { Friendship and Positive Peace: Conceptualising } \\
\text { Friendship in Politics and International Relations }\end{array}$ \\
\hline \multirow[t]{4}{*}{ III. Emotions in International Relations } & Simon Koschut & $\begin{array}{l}\text { Appropriately Upset? A Methodological Framework } \\
\text { for Tracing the Emotion Norms of the Transatlantic } \\
\text { Security Community }\end{array}$ \\
\hline & Trineke Palm & $\begin{array}{l}\text { Interwar Blueprints of Europe: Emotions, Experience } \\
\text { and Expectation }\end{array}$ \\
\hline & $\begin{array}{l}\text { Tereza Capelos \& } \\
\text { Stavroula Chrona }\end{array}$ & $\begin{array}{l}\text { The Map to the Heart: An Analysis of Political } \\
\text { Affectivity in Turkey }\end{array}$ \\
\hline & Eleni Braat & $\begin{array}{l}\text { Loyalty and Secret Intelligence. Anglo-Dutch } \\
\text { Intelligence Cooperation During World War II }\end{array}$ \\
\hline
\end{tabular}


Amy Skonieczny (2018) also contextualises her approach through the 2016 US election; in this case, the candidacy of Donald Trump and Bernie Sanders. A psychoanalytic narrative framework is applied to the populist phenomenon in US politics, with an especial focus on Donald Trump and Bernie Sanders at the time of their candidacy. Populism is, through Skonieczny's (2018) framework, a discursive narrative that allows for a comprehensive investigation of its more emotional elements.

Jo Warner (2018) provides legitimacy for an inclusion of emotions within political representation; in this context, the representative responsibilities and efforts of British Members of Parliament (MP) in relation to child protection. This topic is examined through MPs' efforts to embody their constituencies in collective emotional responses, defending their respective constituencies from feelings of guilt and shame, apportioning blame in relation to personal feelings of guilt, and the role of the MP as an envoy for anxieties about risk to individual children.

Alex Prior (2018) echoes the importance of political representation within discussions of parliamentary politics. Parliament's role-rather than that of parliamentarians-is the focus here, with especial emphasis on attempts to engage citizens through storytelling techniques. These techniques are analysed on the basis of their fidelity to narrative theory, the way in which they represent parliament and citizens to each other (and to themselves), and their construction (and, by extension, presupposition) of an 'audience' that would feasibly engage as a result.

\subsection{Part II: Conceptual Approaches}

In bringing these discussions into more conceptual territory, Anna Durnova (2018)-working within the field of Policy Studies-calls for a dismissal of the binary relationship between emotions and 'meaning', and specifically a shift in focus (based upon the work of Foucault and Deleuze) toward adopting an emotions-based theoretical framework through which to view subjective and collective interpretations of meaning.

As discussed earlier in this introduction, one of the most intriguing (and widely-debated) aspects of the study of emotions is the degree to which emotions are dichotomised with concepts like reason and rationality. For example, as Rosa Sanchez Salgado's (2018) article points out, Civil Society Organizations (CSO) based within the European Union pursue an image of professionalism and expertise that could be considered at odds with emotions and feelings (especially with reference to the traditional conceptualisations earlier). Sanchez Salgado (2018), in investigating this interplay, examines the use of emotions (and emotional appeals) in the advocacy strategies of EU-based CSOs. These communications encompass appeals to reason, but also appeals to emotions used within the framework of advocacy strategies such as 'blaming and shaming'.
Yuri van Hoef and Andrea Oelsner (2018) present an overview of the current status of friendship studies, paying special attention to the overlooked role affect plays in political friendship. Building forth on this insight, they argue that studying friendship is of particular relevance to fields such as Peace and Conflict Studies, where it addresses the lacuna of research on positive peace. They provide several theoretical conceptualisations and methodological approaches that can be readily applied when making sense of friendship, both on a personal level between elite actors, and on the international level between states.

\subsection{Part III: Emotions in International Relations}

The research of Van Hoef and Oelsner (2018) serves to emphasise the relevance of emotions to International Relations, a theme that the third section of the thematic issue focuses upon. The relationship between norms and emotions-as well as their importance to collective selfimage(s) -also forms an area of focus for Simon Koschut (2018). This study pursues a methodology for studying the integration of norms and emotions (in the form of 'emotion norms') within the transatlantic security community by tracing their prevalence historically, through texts that-in terms of self-conception and self-imagecould be considered canonical.

Similar to Koschut's (2018) approach, Trineke Palm (2018) developed an emotion discourse analysis to the study of interwar Europe and its variously idealised end states, themselves based upon normative and moral claims. Drawing on Koselleck's concepts of 'space of experience' and 'horizon of expectation', Palm applied an emotional framework to Coudenhove Kalergi's canonical text Pan-Europa to examine the emotional and normative underpinnings of ideas about European unity and integration.

Building on this question of binary conceptualisations, Tereza Capelos and Stavroula Chrona (2018) investigate (and 'map') political affect 'clusters' that reach beyond (and problematise) traditional compartmentalisations of emotions (such as anger, hope, pride and fear). The authors discuss a rich and nuanced variety of emotional attitudes among the citizenry-shaped in their own right by ideological orientations - the significance of which goes far beyond the field of Turkish politics (serving as their case study).

Continuing with this international focus, Eleni Braat (2018) concludes the thematic issue by applying the study of emotions to a more (literally) elusive phenomenon-wartime intelligence-and the importance of ostensibly nebulous concepts like loyalty in building and maintaining its underlying networks and collaborative efforts, in comparison to formal work processes. This serves to reflect and encapsulate the broader relevance of this thematic issue, in advocating the relevance of emotions within formal (and informal) political processes. 


\section{Conclusion}

The tripartite structure of this thematic issue offers scholars several fruitful avenues to study emotions in the humanities and social sciences. The first part emphasizes the relevance of emotions within discussions of political actors, representatives and institutions, offering a practical approach to make sense of emotions in politics. This is followed by several conceptual studies that offer a myriad of ways to make sense of emotions conceptually, which builds a bridge towards the third part of this thematic issue on approaches to studying emotions within the field of International Relations. Each of the individual contributions offers an invaluable scholarly approach to the study of emotions. They also offer detailed studies of emotions within their subdisciplines; their relevance, salience, and applications.

\section{Acknowledgments}

This thematic issue is a result of two conferences: (1) CIAP2016, Emotions in Politics and International Relations, 20-21 October at the University of Leeds, for which funding was provided by BISA, PSA, and the School for Politics and International Studies (POLIS), and (2) CIAP2017, Emotions in Politics and Governance, 18 January 2018 at Canterbury Christ Church University. Gisli Vogler (University of Edinburgh) and Demetris Tillyris (Canterbury Christ Church University) were an invaluable part of the organisation committee of both conferences. We are also very grateful to the team at Politics and Governance, especially Rodrigo Gomes, Cátia Simões, and António Vieira, for their hard work and for providing us with this opportunity.

\section{Conflict of Interests}

The authors declare no conflict of interests.

\section{References}

Beck, U., Giddens, A., \& Lash, S. (1994). Reflexive modernization: Politics, tradition and aesthetics in the modern social order. Cambridge: Polity Press.

Bennett, W. L. (2008). Changing citizenship in the digital age. In W. L. Bennett (Ed.), Civic life online (pp .1-24). Cambridge, MA: MIT Press.

Berenskoetter, F., \& van Hoef, Y. (2017). Friendship and foreign policy. In Oxford research encyclopedia of politics. Retrieved from http://politics.oxfordre.com/ view/10.1093/acrefore/9780190228637.001.0001/ acrefore-9780190228637-e-429

Braat, E. (2018). Loyalty and secret intelligence: AngloDutch cooperation during World War II. Politics and Governance, 6(4), 159-167.

Capelos, T., \& Chrona, S. (2018). The map to the heart: An analysis of political affectivity in Turkey. Politics and Governance, 6(4), 144-158.
Clément, M., \& Sangar, E. (Eds.). (2018). Researching emotions in international relations: Methodological perspectives on the emotional turn. Basingstoke: Palgrave Macmillan.

Durnova, A. (2018). Understanding emotions in policy studies through Foucault and Deleuze. Politics and Governance, 6(4), 95-102.

Hall, C. (2007). Recognizing the passion in deliberation: Toward a more democratic theory of deliberative democracy. Hypatia, 22(4), 81-95.

Jacobi, D., \& Freyberg-Inan, A. (Eds.). (2015). Human beings in international relations. Cambridge and New York: Cambridge University Press.

Jenkins, L. (2018). Why do all our feelings about politics matter? The British Journal of Politics and International Relations, 20(1), 191-205.

Koschut, S. (2018). Appropriately upset? A methodological framework for tracing the emotion norms of the transatlantic security community. Politics and Governance, 6(4), 125-134.

Loader, B. D., Vromen, A., \& Xenos, M. A. (2014). The networked young citizen: Social media, political participation and civic engagement. Information, Communication \& Society, 17(2), 143-150.

Manning, N. (2015). Feeling politics: The importance of emotions for understanding electoral (dis)engagement. In N. Manning (Ed.), Political (dis)engagement: The changing nature of the 'political' (pp. 107-130). Bristol: Policy Press.

Nussbaum, M. (2001). Upheavals of thought. Cambridge: Cambridge University Press.

Nussbaum, M. (2013). Political emotions. Cambridge: Harvard University Press.

Palm, T. (2018). Interwar blueprints of Europe: Emotions, experience and expectation. Politics and Governance, 6(4), 135-143.

Prior, A. (2018). Getting the story right: A constructivist interpretation of storytelling in the context of UK parliamentary engagement. Politics and Governance, 6(4), 83-94.

Sanchez Salgado, R. (2018). The advocacy of feelings: Emotions in EU-based civil society organizations' strategies. Politics and Governance, 6(4), 103-114.

Skonieczny, A. (2018). Emotions and political narratives: Populism, Trump and trade. Politics and Governance, 6(4), 62-72.

Van Hoef, Y. (2018). Interpreting affect between state leaders. Assessing the Churchill-Roosevelt friendship. In M- Clément \& E. Sangar (Eds.), Researching emotions in IR: Methodological perspectives for a new paradigm (pp. 51-73). Basingstoke: Palgrave Macmillan.

Van Hoef, Y., \& Oelsner, A. (2018). Friendship and positive peace: Conceptualising friendship in politics and international relations. Politics and Governance, 6(4), 115-124.

Warner, J. (2018). Emotional interest representation and the politics of risk in child protection. Politics and Gov- 
ernance, 6(4), 73-82.

Weber, A.-K. (2018). The pitfalls of "love and kindness":
On the challenges to compassion/pity as a political emotion. Politics and Governance, 6(4), 53-61.

\section{About the Authors}

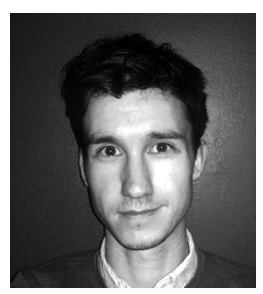

Alex Prior is a Doctoral Researcher at the School of Politics and International Studies (POLIS) at the University of Leeds. His PhD research focuses upon parliamentary engagement initiatives in a sociopolitical context of 'issue politics' and overtly non-deferential modes of political expression. This research also addresses parliaments as sites of symbolic representation and competing, contested narratives. More broadly, his work emphasises the value of narratives and storytelling as theoretical frameworks and, more practically, as devices for strengthening the dynamics that underpin successful engagement.

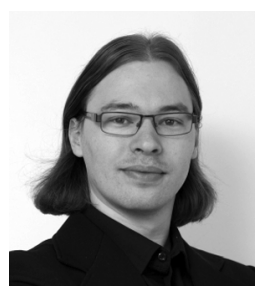

Yuri van Hoef is a Lecturer of Political History and of the History of International Relations at Utrecht University. His research examines the role of friendship in politics. Recent publications include 'Interpreting affect between state leaders. Assessing the Churchill-Roosevelt friendship', edited by Maéva Clémentand Eric Sangar, Researching Emotions in IR: Methodological Perspectives for a New Paradigm (Palgrave Macmillan, 2018), 51-73, and, with Felix Berenskötter, 'Friendship and Foreign Policy', edited by Cameron Thies, Oxford Research Encyclopedia of Politics (Oxford University Press 2017). 